\title{
FINANCIAL ACCOUNTING: AN EPISTEMOLOGICAL RESEARCH NOTE
}

\author{
Eduardo Schiehll \\ PhD, CMA \\ Associate Professor \\ Department of Accounting Studies \\ HEC Montréai - Canada \\ E-mail: Eduardo.Schiehil@hec.ca
}

\author{
José Alonso Borba \\ Professor Doutor do Departamento de Ciências Contábeis \\ do Centro Sócio-Econômico \\ dạ Universidade Federal de Sàntá Catarina - Campus Trindade \\ E-mail:jalonso@cse.ufsc.br
}

\author{
Fernando Dal-Ri Murcia \\ Doutorando em Controladoria e Contabilidade \\ Pela Faculdade de Economia, Administração e Contabilidade \\ da Universidade de São Paulo - Campus Capital \\ E-mail: fernandomurcia@hotmail.com
}

\section{ABSTRACT}

This research note is the result of the authors' reflections on epistemological issues in respect to the financial accounting field. From an epistemological perspective, this document attempts to trace the philosophical, historical, sociological, and discursive research perspectives that have guided academic research in the field of financial accounting. In order to do so, this document explores the distinctions and connections between accounting theory and accounting practice, which we believe is the first step towards understanding accounting as a scientific discipline. We analyze the theories underpinning financial accounting research, discussing its purposes, historic evolution, and scientific methods used. This document also discuss the sociological and discursive contexts of financial accounting in order to demonstrate that, like every other social science, accounting research is based upon assumptions about the nature of it players, or social networks. This document does not have the pretension to cover or close the discussion about all the pitfalls of this complex topic. In this sense, we try to document our analysis and draw some arguments in order to offer evidence for further discussion.

Keywords: Financial accounting. Epistemological view. Accounting theory.

\section{RESUMO}

Este ensaio teórico é resultado de reflexões dos autores acerca de questões epistemológicas sobre a contabilidade financeira. Através de uma perspectiva epistemológica, este trabalho busca traçar perspectivas filosóficas, históricas, sociológicas e discursivas que guiaram a pesquisa acadêmica na área da contabilidade financeira. Para isso, exploramse as similaridades e diferenças entre a teoria e a prática contábil, pois esse é o primeiro para a compreensão da contabilidade como disciplina científica. Analisam-se as teorias que suportam a pesquisa em contabilidade financeira, discutindo seu propósito, evolução histórica e métodos científicos utilizados: O presente trabalho também discute os contextos sociológicos e discursivos da contabilidade financeira como o objetivo de demonstrar que, da mesma maneira que outras ciências sociais, a pesquisa em contabilidade está baseada em pressupostos sobre a natureza de seus atores e/ou ambientes sociais. Finalmente, este trabalho não tem a pretensão de cobrir ou ésgotar todas as discussões sobre as questões que envolvem este complexo tema. Nesta ótica, objetivou-se documentar as análises e extrair alguns argumentos com a finalidade de oferecer evidências para futuros estudos.

Palavras-chave: Contabilidade financeira. Visão epistemológica. Teoria contábil. 


\section{INTRODUCTION}

One of the great attractions of conducting applied research in accounting or any other business field is that the research topics extend beyond the normal boundaries. It brings worldviews into conflict, improves accounting practice, and raises doubts about professional social and values.

This research note is the result of the authors' reflections on epistemological issues in respect to the financial accounting field. The objective is to discuss some of the principles that guide current applied research in financial accounting, without presuming to cover or propose solutions to all the pitfalls of this complex topic. More specifically, from an epistemological perspective, this document attempts to trace the philosophical, historical, sociologi- cal, and discursive research perspectives founded in the financial accounting literature.

The remainder of the paper is organized as follows. In the first section, we explore the distinctions and connections between accounting theory and accounting practice, which we believe is the first step towards understanding accounting as a scientific discipline. The second section outlines the purposes, historic evolution, and scientific methods of financial accounting research. In the third section, we attempt to clarify the sociological and discursive contexts of financial accounting. Finally, we draw some conclusions.

\section{ACCOUNTING THEORY AND ACCOUNTING PRACTICE}

What is accounting? It is amazing how this simple, basic question has never been answered precisely (KAM, 1986). A simple and widely-held concept of accounting is the process of identifying, measuring, recording, and communicating economic information about an organization so that it may be used for sound decision-making. This concept was derived from WELLS (1976), and like other concepts of accounting, it emphasizes the application aspect of accounting knowledge. Viewing this definition from an epistemological perspective, one might argue that the object of study is not well defined, the methodology (truth criteria) is not identified, and the purpose of accounting research is poorly delimited. The aim of this document is not to criticize this specific definition, but to argue that one of the difficulties in understanding accounting as a scientific discipline resides in its definition as stated in the literature. Among others, the importance of viewing accounting as a scientific field is that fundamental or applied research is the only way to generate and improve knowledge in a scientific field. In other words, the relevance of, and incentives for, conducting research in a specific discipline like accounting depend on the extent to which specific methods may be applied to improve the discipline's body of knowledge.

Following this line of reasoning, we believe that in order to perceive and appreciate accounting as a scientific field, a first, essential step would be to understand the distinctions and associations between accounting theory and accounting practice. According to the framework proposed by KUHN (1972), for example, we may conjecture that accounting theory is a body of statements or propositions connected by rules of inferential reasoning (i.e. testable hypotheses or premises and conclusions) that form the general frame of reference for the development or explanation of accounting practices. The study by HENDRIKSEN (1 982) corroborates this argument, adding that accounting theory may be defined as logical reasoning in the form of a set of broad principles that:
(I) provide a general frame of reference by which accounting practice can be evaluated, and

(2) guide the development of new practices and procedures.

According to these principles, we argue that the next step in perceiving accounting as a scientific field would be to identify the accounting theories that are being developed and how they are verified. In this respect, POPPER (1982) suggests that accounting knowledge is a body of normative and positive empirical theories built around inductive inferences.

"Normative" means that accounting theories contain imperative value judgments stemming from factual statements about the object of study, e.g., the market value of firm equity. Another justification is that normative conclusions are very often the origin of policy recommendations, which may or may not be adopted by practitioners in the field. According to WATTS \& ZIMMERMANN (1 986), normative theories are almost entirely devoted to the examination of questions of "what ought to be done." Thus, this theory attempts to prescribe what information ought to be communicated and how it ought to be presented. In other words, the normative theories attempt to explain what accounting "should be" rather than what accounting "is."

On the other hand, positive theories attempt to explain why accounting is what it is. They describe not only what accounting information should and how it should be communicated to its users, but also why accountants do what they do and the effects of all this on people and resource utilization (CHRISTENSON, 1983). However, as suggested by SCHROEDER and CLARK (1995), ideally there should be no such distinction (normative versus positive) because a well-developed and complete theory encompasses both what should be and what it is.

The empirical and inductive attributes of accounting theory are easier to justify. In fact, according to STERLING (1 970), only mathematics and logic can be classified as non-empiri- 
cal sciences. Accounting theories in particular are fundamentally based on experience and observation. For example, the qualitative and quantitative variations of firm equity studied in Financial Accounting, or the dysfunctional behaviors of budgetary control investigated in Management Accounting. However, accounting premises and conclusions are connected by inductive inference. Double-entry bookkeeping system can serve to illustrate this point. The double-entry system is based on noting changes in the wealth of a firm and an attempt to translate the qualitative and quantitative variations in the firm's equity. The double-entry system, perhaps the first and most important paradigm' of accounting science, was invented in the commercial city-states of medieval Italy in response to the emergence of trade and commerce. According to ROVER (1938) the double-entry was born when people came to see that you could not take something out of one pigeonhole without putting it into another. It has emerged as a natural outcome of the evolutionary process to the need of times (KAM, 1986). The first published accounting work was written in 1494 by the Venetian monk Luca Pacioli (1450-1520). It summarizes principles that have remained essentially unchanged to this day.

Subsequent works written in the 16th century introduced the first formulations of the concepts of assets, liabilities, and income. In keeping with this theme, LAKATOS (1978) suggests that a theory is constructed by a body of concepts. From this perspective, assets, liabilities, income, and other notions derived from these such as long and short term, revenue, costs, expenses, operational, no operational, etc., have a specific (or rather particular) meaning in the accounting field, and are fundamental elements for the building and understanding of accounting knowledge. In the same line of thinking, the study by GLAUTIER AND
UNDERDOW (1976) suggests that the concepts of financial accounting are particularly significant to the development of accounting theory in two ways:

(I) they are themselves part of an empirical process for developing rules of financial accounting, and

(2) they reflect the influence of institutional forces which shape the philosophy of accounting in a given and social environment.

Much later, the Industrial Revolution drove the need for accounting practices that could handle mechanization, factory-manufacturing operations, and the mass production of goods and services. With the rise of large, publicly held business corporations owned by absentee stockholders and administrated by professional managers, the accounting role was further redefined. According to SCHOROEDER, CLARK and CATHEY (2005) the Industrial Revolution brought the need for more formal accounting procedures and standards. In terms of epistemology, these two events may be interpreted as a crisis (KUNH, 1972) in accounting science. Organizations were immersed in a new social and economic reality. New paradigms were imposed onto management activities, calling for new accounting theories to support the new accounting practices. From that point on, research in the accounting field split off into two directions: financial accounting and management accounting. While the first focuses on the outside user of accounting information, the second focuses on the internal user and the decision making process. However, independently of this split, theorists continue their quest: explain accounting practice. In the next section we discuss the purposes, evolution and methods of financial accounting research.

\section{FINANCIAL ACCOUNTING RESEARCH: PURPOSE, EVOLUTION, AND METHODOLOGY}

Financial accounting is commonly considered as the process by which a company discloses information about its financial and economic activities to different users outside the organization (CHAMBERS, 1966). Following this line of reasoning, we may argue that financial accounting theories are responsible for setting the rules and principles that guide current financial accounting practice. More specifically, economic theories such as agency and stewardship theories are the underpinnings of accounting standards that require the disclosure of financial information. Also, they are the foundations of the frameworks used by external users to interpret this information. For example, the United States' FAS - Financial Accounting Standards' body of rules, among the most well-known standards in financial accounting, is used as a reference worldwide for preparing, disclosing, or interpreting financial statements.

In the United States for example, financial accounting studies proliferated after the passing of the Securities Acts of 1933 and 1934, which created the Securities Exchange Commission (SEC), a government regulatory agency. Regarding SEC's role in the development of accounting principles, Section 13 (b) of Securities Acts of 1934 states:

"The commission may prescribe, in regard to pursuant to this title, the forms in which required information shall be set forth, the items or details to be shown in the balance sheet and the earnings statement, and the methods to be followed in the preparation of report,......"

At the same time, SEC was also granted the authority to determine external auditing practices. SEC's laws insti-

\footnotetext{
I Both inductive and deductive inferences may generate positive or normative theories. Positive theories attempt to explain what and how accounting information is presented and how it should be communicated to users. Normative theories attempt to prescribe what data ought to be communicated and how they ought to be presented, that is, they attempt to explain what should be rather than what is. WATTS \& ZIMMERMANN (1986).
} 
tutionalized the corporate audit and regulated the financial disclosure of corporations listed on the stock exchange. In this respect, (1982) suggests that the creation of the Security Exchange Commission represents a sea change in basic accounting thought. The SEC's regulatory role changed the goal from presenting information to management and creditors to providing relevant financial information to investors and stockholders, a completely new paradigm for financial accounting

Although SEC had the power to regulate accounting practices and disclosure, in general it has heavily relied on accounting professional and used its power to set constraints and exert veto power (BELKAOUI, 1993). In this same line of reasoning, KAM (1986) states that the philosophy of the SEC has been to permit the private sector to take the leading in formulating accounting principles. In this sense, accounting theorists have became increasingly concerned with prescribing what information should be reported and how. As a result, the accounting field has seen the creation of a plethora of committees to discuss, investigate, and propose new accounting principles and procedures. According to WATTZ and ZIMMERMAN (1986) "accounting theorists became much more concerned with prescribing how firms should report. Very little concern was exhibited for the empirical validity of the hypotheses on which the normal prescriptions rested." Under this normative approach, accounting properties are evaluated in terms of their perceived proximity to the ideal criteria.

That being said, we must also emphasize that the normative approach adopted by financial accounting research in its early stages still predominates today. Two factors appear to have influenced this thinking. First, the main guidelines given to accounting researchers was, and still is, that specific accounting theories should conform to the general principles, which were believed to be grounded in current financial accounting practice. As HENDRIKSEN (1982) points out, if we wish to evaluate current accounting practices, it may be necessary to start identifying the procedures and rules applied in the accounting practice, and from that attempt to establish general presuppositions and theories.

Second, from a sociological perspective, the evolution of financial accounting research was hampered by the involvement and regulatory oversight of governments and professional accounting associations. For instance, the American Accounting Association (AAA), which committees' comprised mainly of accounting educators, and has as a mission "to foster worldwide excellence in the creation, dissemination and application of accounting knowledge and skills", has influenced the development of accounting thought by its research and publication (KAM, 1986).

According to RYAN (1992), simultaneous significant research efforts were being carried out by economists and economics-oriented accountants in the United Kingdom, mainly at the London School of Economics (LSE). Accountants interested in distilling principles from existing practices (the normative approach) were producing inductive theories based on rationalizations of prevailing practices, whereas economists were using economic analysis to critique basic accounting methods. WHITTINGTON (1 987) defined the first approach as empirical inductive and the second as deductive. These different approaches began to converge after the Second World War, leading to the research of the 1960s, known as the "golden age" of a priori research in financial accounting, apparently under the strong influence of the critical ethos of POPPER (1982). According to our analysis, we argue that financial accounting researchers embraced a hypothetical deductive methodology, and attempts were made to derive measures of income that conformed to economic theory and at the same time satisfied the requirements of existing accounting practices. The works of CHAMBER (1966), STERLING (1970), and MATTESSICH (1970) date from that era. It was the first major turning point in accounting methodology.

At that time, one of the primary assumptions in financial accounting was that income measures were needed to assist shareholder and investor decision-making in their ownership interests. This supposition led to the development of the predictive ability criterion in financial accounting research. The predictive approach steered a new set of empirical studies towards the effects of accounting information on decision-making. These studies examined, for example, the behavior of decision-makers faced with different types and reporting intervals of accounting information. Owing to the difficulty of determining future cash flows, these studies generally contented themselves with examining the relationship between accounting information and current share prices. The seminal works of BEAVER (1968) and BALL and BROWN (1968) represent the shifted in accounting research, as the normative approach began to be replaced by the informational approach. This is reflected in financial accounting research in information economics, securities prices, and behavioral sciences (BEAVER, 1998).

This kind of research enjoyed great popularity during the 1970s, and was mostly grounded on finance theories such as the Capital Asset Pricing Model (CAPM) and the Efficient Market Hypothesis (EMH). Accordingly, accounting studies from that period are characterized by the progressive introduction of finance research methods, accompanied by the growing presence of positive theory and methodology. As a result, empirical works were marked by contradictions between the positive concept and hypotheses that underlay the normative prescriptions of early accounting.

This shift to an informational approach in financial reporting is also emphasized in the Financial Accounting Standards Board's Statement № I (1978), which states that:

"Financial reporting should provide information that is useful to present and potential investors and creditors and other users in assessing the amounts, timing, and uncertainty of prospective cash receipts"

According to Beaver (1998) one of the reasons for this shift was that the concept of economic income had not been well-defined when there were imperfect or incomplete markets. 
In 1986, a new methodology was formally introduced into financial accounting research, with a significant impact on research directions. It was called Positive Accounting Theory, ${ }^{2}$ and was invented in North America at the Universities of Chicago and Rochester by WATTS $\varepsilon$ ZIMMERMAN ( 1 986). Positive Accounting Theory represented an extreme form of empiricism, and a reaction to the normative methodology of the a priori theorists that had reigned for previous decades.

The main argument of WATTS $\&$ ZIMMERMAN (1 986) is that scientific research may concern itself only with "what is" questions, that is, it must follow a predictive approach. In other words, accounting research cannot be used to answer "ought to be" questions (the prescriptive or normative approach discussed previously). Thus, positive accounting postulates that accounting research can be used to predict stock market reactions to the disclosure of accounting information, but cannot prescribe how income ought to be measured in financial statements or how stock prices ought to be evaluated based on accounting information. The authors of the positive accounting theory also advised careful discrimination between positive and normative propositions. For example, the positive perspective is concerned with how the world works and how accounting information is interpreted. Let's say a firm switches its inventory evaluation method from FIFO to $\mathrm{LIFO}^{3}$. Because the stock market has not anticipated the change, the stock price rises. This result can be interpreted under the positive perspective ("what happens"). A normative proposition however, being prescriptive, would suggest that, because prices are rising, the LIFO system should be adopted. This epistemological change in financial accounting theory can be thought of as a revolution (KUHN, 1972) in accounting science, in which the consensus associated with the old paradigm is replaced by consensus on the new paradigm, in this case, a predictive approach.

The Positive Theory was generally welcomed into financial accounting research, inspiring Efficient Market Hypothesis testing and research based on the assumptions of neoclassical economics, portfolio, and agency theories. Since then, these topics have been the predominant focal areas in financial accounting research. Notwithstanding, in recent years the Positive Accounting Theory has been subjected to harsh critiques from positive theorists like CHRISTENSON (1983) and WHITTINGTON (I 987). Its detractors have pointed out the impossibility of divorcing empirical testing from theoretical assumptions. The most telling argument is that the design of any empirical test requires theoretical constructs, and a positive theory inevitably contains theoretical assumptions.

In our opinion, here again the evolution of financial accounting research, theory, and practice can be viewed through KUHN's (1972) concept of science. According to this author, criticism should be interpreted as a pre-paradigm stage, during which a body of phenomena is examined by scientists espousing competing schools of thought with no common body of belief. As FEYERABEND (1979) puts it, "La science est anachiste" (science is anarchist). If this turmoil is inherent in the very scientific process itself, then accounting and financial accounting theory must necessarily be a contentious process.

As the new millennium approached, financial accounting theory and practice seemed to be doing quite well, as financial markets were booming across capitalism countries. However, in the beginning of this decade, accounting has suffered a huge loss, as public confidence in financial reporting started to erode. Fraud scandals involving corporations like Enron, WorldCom, Adelphia, Global Crossing, Parmalat, Lucent, Tyco and Xerox have resulted in financial statement's credibility loss, raising questions about the integrity of the accounting and the auditing professions.

As former SEC's president states LYNN TURNER (1 999) states

"Given the fact that accounting is done by people, I do not expect us to be able to totally eliminate fraud. However, we shouldn't ignore it but rather proceed with timely and appropriate enforcement actions."

Following this line of reasoning, we seem to be entering into a new paradigm, where the main concern is to recovery public trust in financial reporting. In the United States, for example, the Sarbanes-Oxley Act, enacted in 2002, wishes to attribute higher accountability to executives and companies involving in financial statement fraud. Accounting research has also been influenced by these events as topics like corporate governance, business ethics, earnings management, report restatement, manager's compensation and incentives, fraud red flags, forensic accounting, continuous auditing and whistle-blowing have been lately addressed by the scientific community.

In the next section we follow this epistemological analysis of the financial accounting discipline exploring its sociological and discursive roots.

\section{THE SOCIOLOGICAL AND DISCURSIVE PERSPECTIVES OF ACCOUNTING}

The studies by LATOUR (1989) and WHITLEY (1984) suggest that the sociological and discursive perspectives of a science are basically determined by the extent and intensity of its interaction with society. Like every other social science,

2 In positive or scientific theory there are no brute facts. The interpretation of facts depends on theories. Furthermore, we cannot prove a hypothesis correct. All that is possible is to disprove a hypothesis. POPPER (1963).

3 First in first out (FIFO) and Last in last out (LIFO). 
accounting conducts its research based upon assumptions about the nature of social science and the nature of society (BELKAOUI, 1997). As it happens, financial accounting may be analyzed from both the sociological and discursive perspectives. Thus, accounting may be viewed as a "socio-systemic" structure, with input, process, and output. The idea is that financial accounting knowledge does not affect only the accountants and accounting practices, but also (directly or indirectly) impacts the management context in all its ramifications. As BEAVER (1998) suggests, the current financial report environment consists of various groups (investors, information intermediaries, regulators, managers, auditors, etc.) who are affected by and have a stake in financial reporting requirements. Hereafter, the sociological and discursive perspectives of accounting will be analyzed assisted by the strong interdependence between science and society (the science "players"). Our argument is that, as an applied science, the accounting discipline is no exception to the rule.

In this sense, the process of constructing accounting theories has been analyzed, culminating in the conclusion that market pressure, tax laws (institutional influence), management decision needs, and macroeconomic factors such as inflation are the main inputs to a sociological accounting system. These inputs are the starting points for an accounting translation process. Thus, the discursive result is the creation or improvement of accounting practices, while the sociological contribution is the correct incorporation of these aspects into the accounting framework to address user needs and serve as interpretation models. Therefore, the accounting "socio-output" is represented by better assessments of a firm's financial health by investors and stakeholders and improved decision-making by managers. Thus, selection of a financial reporting system might be viewed as a social choice, where bargain power will determine whoever gets their desires fulfilled.

In a number of countries, such as the United States, where financial reporting information is directed primarily toward the needs of investors and creditors, decision usefulness is the overriding criterion for judging its quality (MUELLER, GERNON and MEEK, 1994). However, in some other countries, such some Latin American countries, financial accounting is designed primarily to ensure that the right amount of tax is collected. In this sense, accounting is shaped by the environmental forces in which it operates.
At the same time, scientific research in accounting has also been influenced by social and environmental forces, which resulted in two different streams of research: the North-American and the European. According to LOPES and MARTINS (2005) research in accounting cannot be considered independently of the social environment in which it is inserted. The research itself is a product of the social environment.

The North American stream of accounting research, which is known as the mainstream, has been based on the economic concepts and in a framework based on the positive method, which basically relies on:

(i) hypotheses development

(ii) economic theories to support the hypotheses

(iii) empirical tests using econometrics techniques

(iv) conclusions that wish to construct a theory in order to explain and predict particle

This line of research has been largely disseminated by the Elite Schools (Chicago, MIT, Rochester, Stanford, etc.) and their PhDs programs. This research has also been stimulated by premier scientific journals like The Accounting Review (TAR), Journal of Accounting Research (JAR), Journal of Accounting and Economics (JAE), Contemporary Research (CAR) and Review of Accounting Studies (RAS).

However, an alternative stream of research has emerged with the foundation of the journal Accounting, Organization and Society, in England. Here, we call it the European or British stream, as most of the researches were originally British like Antony Hopwood, Michael Power and Peter Miler. However, we might note the existence of British authors that are adopters of the "North-American approach" and vice-versa.

The theoretical approach used by the British stream of research has been based on disciplines like sociology, psychology, history and political economy. In this line of research, the accounting phenomenon cannot be viewed within the best possible option (normative) or a set of hypotheses to be tested (positive); instead the proposition is that forces that shape accounting should be elaborated within a set of social interactions that act in a debate arena (LOPES and MARTINS, 2005)

\section{FINAL REMARKS}

This brief epistemological overview of the history of financial accounting research demonstrates how it gained importance as a hands-on activity before the accounting theorists arrived on the scene. Consequently, accounting practices were shaped by accounting practitioners and the government authorities, which took a keen interest in the protection of capital markets and creditors. The capital market still wields a strong influence over the sociological and discursive branches of financial accounting science. Research programs have been supported by regulatory bodies such as AICPA (USA) and CICA (Canada) and professional accounting associations such as $A A A$ (USA) and CAAA (Canada) ${ }^{4}$.

4 AICPA is the acronym for American Institute of Certified Public Accountants; CICA is the acronym for Chartered Accountants of Canada; AAA is the acronym for American Accounting Association; and CAAA is the acronym for Canadian Academic Accounting Association. 
Financial accounting research has also been impacted by the corporative influence. This influence has taken the form of standards designed to control financial accounting practices instead of fostering discussion on the anomalies between the reality and evaluation of firm equity. As a consequence, few paradigms or accounting theories have been put forward to guide research avenues in financial accounting. When Positive Accounting Theory brought to accounting a theory-testing approach, researchers embarked on an efficient capital market approach, which led to improved utilization of rigorous research methods and statistical analysis. These factors may have shielded financial accounting from criticism, and therefore creativity, compared to other management disciplines, where there was more incentive for qualitative and interpretative investigation.
At the same time recent accounting scandals involving highly known corporations have raised questions about financial report's reliability, which seem to somehow shifted the focus back to regulation that could result in less information usefulness, in order to recover the integrity of accounting information. As such, researchers in financial accounting need to be aware of the many dimensions and realities that they are attempting to "account for" and represent. Numerical Accounting highlights aspects of organizational reality that are quantifiable and built into the accounting framework, but oftentimes ignore aspects of organizational reality that are not quantifiable in this way. That said such challenges are part and parcel of all scientific fields.

\section{References}

BAO, D. H.; BERK, J. Trends in Evolution of Scholarly Accounting Thought: a quantitative examination: The Accounting Historians Journal, Spring, p. 45-64, 1988.

BEAVER, W: Financial Reporting: an accounting revolution. $3^{\text {rd }}$ ed. Prentice Hall, 1998.

BELKAOUI, A. Accounting Theory. $3^{\text {rd }}$ ed. Dryden Press, 1993.

Research Perspectives in Accounting. $1^{\text {st. }}$ ed. Quorun Books Inc, 1997.

CHAMBERS, J. C. (1966), Accounting, Evaluation and Economic Behavior., $1^{\text {st }}$ ed: New Jersey: Prentice-Hall, Inc.; Englewood Cliffs, p. 338 , chap: 1-3.

CHRISTENSON, C. (1983), The Methodology of Positive Accounting. The Accounting Review, v. 58, n. 1, p. 1-22.

FEYERABEND, P. Contre la Méthode. Paris: Seuil, p. 13-70, 1979.

GLAUTIER, M.; UNDERDOWN, B. Accounting Theory and Practice. $5^{\text {th }}$ ed. Pitman Publishing, 1994.

HENDRIKSEN, E. S. Accounting Theory. $4^{\text {th }}$ ed. Illinois: Richard D. Irwin, Inc, p. 589, chap. 1-4, 1982.

KAM, V. Accounting Theory. $2^{\text {nd }}$ ed. Wiley Inc, 1986.

KUHN, T. S., The Structure of Scientific Revolutions, $1^{\text {st. }}$ ed. Chicago: University of Chicago Press, 1972.

LAKATOS, I. The Methodology of Scientific Research Programmes. In: The Methodology of Scientific Research Programmes, Philosophical Papers, v. 1. Cambridge: Cambridge University Press, p. 8-101, 1978.

LATOUR, B. La science en action. Paris : Les Éditions de la Découverte, p. 7-96, 1989.

LOPES, A; MARTINS, E. Teoria da Contabilidade: uma nova abordagem. Editora Atlas, 2005.

MATTESSICH, R. Some Thoughts on the Epistemology of Accounting. Reprinted of the Second International Conference on Accounting Education. London: University of British Columbia; Vancouver, Canada, p. 32, 1970.

MORGAN, G. Accounting as reality construction: towards a new epistemology for accounting practice. Accounting, Organizations and Society, y. 13, n. 5 , p. $477-585,1988$.

MUELLER, G.; GERNON, H; MEEK, G. Accounting: an International Perspective. Irvin Editors, 1994.

POPPER, K. R. Examen de certains problèmes fondamentaux: La logique de la découverte scienfitique. Paris: Payot, p. $23-45,1982$.

ROOVER, R. de Characteristics of Bookkeeping before Paciolo. Accounting Review, p. 146, 1938.

RYAN, B. et al. Research Method and Methodology in Finance and Accounting. San Diego: Academic Press Inc, p. $208,1992$.

SARBANES-OXLEY ACT OF 2002. Disponível em: <http://www.sarbanes-oxley.com>.

SCHROEDER, R.; CLARK, M. Accounting Theory: texts and readings. $5^{\text {th }}$ ed. Willey Inc, 1995.

; CLARK, M.; CATHEY, J. Financial Accounting Theory and Analysis: texts and readings. $\dot{8}^{\text {th }}$ ed. Willey Inc, 2005.

STERLING, R. R. On Theory Construction and Verification. The Accounting Review, p. 444-457, july 1970.

TURNER, L. Speech by SEC Staff: Panel on Audit Effectiveness. U.S. Securities and Exchange Commission, october 7, 1999.

WATTS, R. L.; ZIMMERMAN, J. L. Positive Accounting Theor. $1^{\text {st. }}$ ed. Englewood Cliffs, New Jersey: Prentice-Hall, Inc, p. 388, chap. 1-3; 12-14, 1986.

WELLS, M. C. Revolution in Accounting Thought? The Accounting Review, v. 51, p. 471-482, july 1976. 
WHITLEY, R. D. The possibility and utility of positive accounting theory. Accounting, organizations and Society, v. 14, n. 6, p. 631-645, 1989. WHITLEY, R. The Organizational Structures of Scientific Fields. The Intellectual and Social Organization of the Science, Oxford, Clarendon Press, p. 153-218, 1984.

WHITTINGTON, G. Positive Accounting: a review article. Accounting and Business Research, v. 17, n. 68, p. $327-336,1987$.

\section{NOTA - Endereço dos autores}

HEC Montréal

3000, chemin de la Côte-Sainte-Catherine Montréal (Québec)

Canada H3T 2A7

Universidade Federal de Santa Catarina

Centro Sócio-Econômico

Trindade - Florianópolis - SC

$88040-900$
Universidade de São Paulo

Faculdade de Economia, Administração e Contabilidade

Departamento de Contabilidade e Átuária

Av. Prof. Luciano Gualberto, 908 - prédio 3 - Cidade Universitária

São Paulo - SP

05508-900 